\title{
Beta of Viet Nam Listed Computer and Electrical Company Groups during and after the Financial Crisis 2007-2011
}

\author{
Dinh Tran Ngoc Huy \\ Banking University, HCMC - GSIM, Intl. University of Japan, Japan \\ E-mail: dtnhuy2010@gmail.com
}

Received: March 19, 2013 Accepted: April 4, 2013 Published: June 1, 2013

doi:10.5296/ajfa.v5i1.3411ＵRL: http://dx.doi.org/10.5296/ajfa.v5i1.3411

\begin{abstract}
During and after the financial crisis 2007-2011, the Viet Nam stock market, generally, has unexpected fluctuations and VNI-Index has decreased. Besides, the Viet Nam computer and electrical industry, specifically, has to re-evaluate the risk level.

First, we estimate asset and equity beta of four (4) sub-industrial listed companies in Viet Nam computer and electrical industries by using a proper traditional model. We found out that the mean value of beta of total 64 firms used in this research is around 0,711 , which is quite acceptable.

Second, through comparison among four (4) different groups, we find out that the values of beta during the period 2007-2011 of listed hardware companies vary less than those of the rest three (3) listed groups: software, electrical and comm./telecommunication firms.

Finally, this paper provides both internal and external investors, financial institutions, companies and government more evidence in establishing their policies in investments and in governance.
\end{abstract}

Keywords: Equity beta, Financial structure, Financial crisis, risk, Asset beta, Computer and electrical industry

JEL Classification: G010, G100, G390 


\section{Introduction}

Although measuring beta is a traditional method used in lots of studies by researchers, this paper emphasizes on analyzing it in computer and electrical industry in one of emerging markets: Vietnam stock market during the financial crisis 2007-2011. After the previous published article on estimated beta for listed construction company groups, here, we will compare the estimated results of listed Viet Nam electrical and electronic companies to those in its supply chain activities such as software, hardware and comm../telecommunication companies to make a comparative analysis and risk evaluation after financial crisis impacts. No research, so far, has been done on the same topic.

This paper is organized as follow. The research issues and literature review will be covered in next sessions 2 and 3, for a short summary. Then, methodology and conceptual theories are introduced in session 4 and 5. Session 6 describes the data in empirical analysis. Session 7 presents empirical results and findings. Then, session 8 gives analysis of risk. Lastly, session 9 will conclude with some policy suggestions. This paper also provides readers with references, exhibits and relevant web sources.

\section{Research Issues}

We mention a couple of issues on the estimating of beta for listed computer and electrical companies in Viet Nam stock exchange as following:

Hypothesis/Issue 1: Among the four (4) companies groups, under the financial crisis impact and high inflation, the beta or risk level of listed companies in electrical and electronic industries will relatively higher than those in the rest three (3) industries.

Hypothesis/Issue 2: Because Viet Nam is an emerging and immature financial/technological market and the stock market still in the recovering stage, there will be a large disperse distribution in beta values estimated in the computer and electrical industries.

Hypothesis/Issue 3: With the above reasons, the mean of equity and asset beta values of these listed computer and electrical companies tend to impose a high risk level, i.e., beta should higher than $(>) 1$.

\section{Literature Review}

Certainly, beta, as a market risk measure, has certain influence on expected stock returns. As Sharpe, Lintner (1964), and Black. (1972) with CAPM model identified the expected stock return is linearly proportional to its market beta. Fama and French (2004) also indicated in the three factor model that "value" and "size" are significant components which can affect stock returns. They also mentioned that a stock's return not only depends on a market beta, but also on market capitalization beta. The market beta is used in the three factor model, developed by Fama and French, which is the successor to the CAPM model by Sharpe, Treynor and Lintner. Pereiro, Luis E (2010) said in merging markets, measuring betas is more difficult and a complicated job because developed markets have abundant historical data. And there might be no comparable local firms and this may cause unreliable CAPM betas. 
And the task of estimating cost of equity in emerging markets is more difficult because of problems such as collecting data in short periods. Then, Velez-Pareja (2011) referred to the lack of inadequate information on the stock market in emerging countries may undermine beta and relevant formulas. Frazzini and Pedersen (2011) stated risky high-beta assets require lower risk-adjusted returns than low-beta assets. Marcin, Mariusz, Marek and Carol (2012) pointed calculated single betas in emerging markets can move counter to the market. They mentioned that the reliability and fitness of calculated betas are relevant to the valuation and investment of investors in merging markets. And Xiaowei Kang (2012) found that combining weighted or alternative beta strategies can gain significant traction in investment community and reduce risk.

Next, Pablo Fernandez (2013) also stated that industry betas are very unstable.

Finally, a portfolio beta can be calculated by taking market capitalization of each stock in the portfolio and then, average beta of each company security.

\section{Conceptual Theories}

\section{Determinants of Equity and Asset Beta}

In financial markets, systematic risk relates to the overall risk of the whole market, is affected by some factors such as: interest rate fluctuations or economic crisis, can not be avoided by diversification, and is measured by a financial metric, beta.

Unlevered beta measures how much systematic risk a firm has, without debt, compared to the benchmark in the stock market. Equity beta covers systematic risk of a firm's equity while asset beta mentions that risk which a firm's asset has.

Several factors affecting beta include, but not limit to, the volatility of expected return of a single stock, or the volatility of the expected return of the entire stock market index. Therefore, the company performance or its management performance, the investor confidence and the economic expectation might influence beta values.

Last but not least, for a typical company, its beta can be estimated by using a regression against an overall stock exchange index.

\section{Methodology}

We use the input data from the live stock exchange market in Viet Nam during the four or five years of financial crisis 2007-2011 to estimate results. We do research in this period because Viet Nam stock market has the declining trend and this is the time highlighting financial crisis impacts.

Firstly, we use the market stock price of 64 listed companies in the electrical and electronic, software, hardware, and comm./telecommunication industries in Viet Nam stock exchange market to calculate the variability in monthly stock price in the same period; secondly, we estimate the equity beta for these 4 listed groups of companies and make a comparison. Thirdly, from the equity beta values of these listed companies, we perform a comparative analysis between equity and asset beta values of these 4 companies groups in Viet Nam. 
Finally, we use the results to suggest policy for both these enterprises, financial institutions and relevant organizations.

The below table gives us the number of computer and electrical firms used in the research of estimating beta:

\begin{tabular}{|l|l|l|l|l|l|}
\hline Market & $\begin{array}{l}\text { Listed Electrical and } \\
\text { Electronic equipments } \\
\text { companies (1) }\end{array}$ & $\begin{array}{l}\text { Listed } \\
\text { Software } \\
\text { companies (2) }\end{array}$ & $\begin{array}{l}\text { Listed } \\
\text { Hardware } \\
\text { companies (3) }\end{array}$ & $\begin{array}{l}\text { Listed Comm. And } \\
\text { Telecommunicatio } \\
\text { n companies (4) }\end{array}$ & Note (4) \\
\hline Viet Nam & 14 & 5 & 14 & 15 & $\begin{array}{l}\text { Estimating by } \\
\text { traditional } \\
\text { method }\end{array}$ \\
\cline { 2 - 6 } & 4 & 1 & 8 & 3 & $\begin{array}{l}\text { Estimating by } \\
\text { comparative } \\
\text { method }\end{array}$ \\
\hline Total & 18 & 6 & 22 & 18 & $\begin{array}{l}\text { Total firms in } \\
\text { group: } 64\end{array}$ \\
\hline
\end{tabular}

(Note: The above data is at the December $12^{\text {th }}, 2012$, from Viet Nam stock exchange)

\section{General Data Analysis}

In an industrial sample with 64 firms, equity beta is calculated at a value of 0,690 (mean) and that of asset beta is about 0,415 which are good numbers, relating to market risk during the crisis. Besides, that sample variance of equity beta is 0,1804 and that of asset beta is 0,1201 is acceptable, even though the range of max and min value of beta is still large.

Value of equity beta varies in a range from 2,056 (max) to -0,524 (min) and that of asset beta varies in a range from 1,941 (max) to $-0,251$ (min). This shows us a few companies still has larger risk exposure than most of the others. Looking at table 2, we note that there are 17 firms in the computer and electrical industrial sample has beta values higher $(>)$ than 1 .

Next, Asset beta max value is 1,941 and min value is $-0,251$ which show us that though beta of debt is assumed to be zero (0), the company's financial leverage contributes to a decrease in the market risk level. Asset beta's mean value at 0,415 and sample variance at 0,1201 , together are good risk numbers for companies in the industry.

Lastly, we can see the small difference between equity and asset beta variance values is just 0,0604 and that b.t equity and asset beta mean is about 0,2749; so, there is not big effect from financial leverage on the gap between company's beta values and industry mean value, although it indicates again that financial leverage can enable computer and electrical firms to reduce market risk. 
Table 1. Estimating beta results for Four (4) Viet Nam Listed Computer and Electrical Companies Groups (as of Dec 2012)

\begin{tabular}{|l|c|c|c|}
\hline Statistic results & Equity beta & Asset beta (assume debt beta = 0) & Difference \\
\hline MAX & 2,056 & 1,941 & 0,1148 \\
\hline MIN & $-0,524$ & $-0,251$ & $-0,2732$ \\
\hline MEAN & 0,690 & 0,415 & 0,2749 \\
\hline VAR & 0,1804 & 0,1201 & 0,0604 \\
\hline \multicolumn{3}{|c|}{ Note: Sample size $: 64$} \\
\hline
\end{tabular}

source: Viet Nam stock exchange data

Table 2. The number of companies in research sample with different beta values and financial leverage

\begin{tabular}{|c|c|c|c|}
\hline Beta & No. of firms & Financial leverage (average) & Ratio \\
\hline$<0$ & 2 & $41,29 \%$ & $3 \%$ \\
\hline $0<$ beta $<1$ & 45 & $47,67 \%$ & $70 \%$ \\
\hline Beta $>1$ & 17 & $36,88 \%$ & $27 \%$ \\
\hline Total & 64 & $44,4 \%$ & $100 \%$ \\
\hline
\end{tabular}

\section{Empirical Research Findings and Discussion}

\section{A-Electrical and Electronic listed companies group}

During the crisis 2007-2011, the market for these companies still exists, but has certain difficulties. Demand for cable and electrical wire decreases whereas demand for optical cable is still good. Some companies have to seek foreign partners and markets.

From the Table 3 below, from data of 18 electrical/electronic industry companies during 2007-2011 crisis periods, the variance of equity and asset beta of sample group equals to 0,1749 and 0,07 accordingly which lower than the variance of the entire sample equity and asset beta of $\mathbf{0 , 1 8 0 4}$ and $\mathbf{0 , 1 2 0 1}$. The beta mean values are 0,626 and 0,327 , lower than $(<) 1$, which indicates the low risk level for electrical/electronic companies. Reasons include the high demand of accommodation, housing and leasing in a developing country, Viet Nam.

We might note that equity and asset beta values of 18 firms in this category are lower than those of firms in the rest three (3) groups. Although lending organizations can not reduce borrowing costs immediately, and this threats the cost of capital of these companies, the good market and management can be critical factors to explain this phenomenon.

Besides, the estimated equity beta mean is $\mathbf{0 , 6 2 6}$ and sample variance is $\mathbf{0 , 1 7 4 9}$, which is not supporting our $2^{\text {nd }}$ research hypothesis or issue that there would be a large disperse distribution in beta values estimated in this industry as well as our $3^{\text {rd }}$ research hypothesis or issue that the mean of equity and asset beta values of these listed companies tend to impose a high risk level or beta should higher than $(>) 1$. 


\section{Macrothink}

Asian Journal of Finance \& Accounting ISSN 1946-052X 2013, Vol. 5, No. 1

Table 3. Estimating beta results for Viet Nam Listed Electrical and Electronic Equipment Companies (as of Dec 2012) (source: Viet Nam stock exchange data)

\begin{tabular}{|c|c|c|c|c|}
\hline $\begin{array}{c}\text { Order } \\
\text { No. }\end{array}$ & $\begin{array}{l}\text { Company stock } \\
\text { code }\end{array}$ & Equity beta & $\begin{array}{l}\text { Asset beta (assume } \\
\text { debt beta }=0 \text { ) }\end{array}$ & Note \\
\hline 1 & $\underline{\mathrm{TSB}}$ & 0,376 & 0,102 & \multirow{18}{*}{$\begin{array}{l}\text { BTH as comparable } \\
\text { NHW as comparable }\end{array}$} \\
\hline 2 & $\underline{\mathrm{BTH}}$ & 0,701 & 0,465 & \\
\hline 3 & $\underline{\mathrm{DZM}}$ & 1,372 & 0,551 & \\
\hline 4 & $\underline{\mathrm{DVH}}$ & 0,136 & 0,041 & \\
\hline 5 & $\underline{\mathrm{LGC}}$ & 0,890 & 0,361 & \\
\hline 6 & CJC & 0,587 & 0,091 & \\
\hline 7 & TYA & 1,145 & 0,359 & \\
\hline 8 & PPS & 0,092 & 0,007 & \\
\hline 9 & GLT & 0,687 & 0,482 & \\
\hline 10 & $\underline{\mathrm{NAG}}$ & 1,220 & 0,472 & \\
\hline 11 & $\underline{\mathrm{NHW}}$ & 0,225 & 0,087 & \\
\hline 12 & $\underline{\text { FBA }}$ & 0,543 & 0,390 & \\
\hline 13 & $\underline{\text { SMA }}$ & 0,039 & 0,005 & \\
\hline 14 & $\underline{\text { TIE }}$ & 0,620 & 0,489 & \\
\hline 15 & $\underline{\text { TGP }}$ & 0,349 & 0,121 & \\
\hline 16 & $\underline{\mathrm{VHG}}$ & 1,206 & 0,953 & \\
\hline 17 & $\underline{\mathrm{VBH}}$ & 0,239 & 0,206 & \\
\hline 18 & $\underline{\mathrm{CSG}}$ & 0,851 & 0,706 & \\
\hline
\end{tabular}

Table 4. Statistical results for Vietnam listed Electrical and Electronic Equipment companies

\begin{tabular}{|l|c|c|}
\hline Statistic results & Equity beta & Asset beta (assume debt beta = 0) \\
\hline MAX & 1,372 & 0,953 \\
\hline MIN & 0,039 & 0,005 \\
\hline MEAN & 0,626 & 0,327 \\
\hline VAR & 0,1749 & 0,0700 \\
\hline \multicolumn{2}{|c|}{ Note: Sample size : 18} \\
\hline
\end{tabular}

\section{B- Software listed companies group}

In an emerging market such as Viet Nam, the market for software firms is definitely potential, though it may be affected by impacts from the financial crisis.

The Table 5 below shows us the equity and asset beta mean of 6 listed software companies equals to 0,725 and 0,445 , accordingly. This result, which means the risk is acceptable 
although they are a little bit higher than that of the electrical/electronic firms, maintains the investor confidence of business operation of the whole industry.

Besides, the distribution of beta value among these 6 firms is normal, from 0,125 to 1,112 and from 0,088 to 1,019 , for equity and asset beta, accordingly.

Please refer to Exhibit 2 for more information.

Table 5. Statistical results for Vietnam listed Software companies

\begin{tabular}{|l|c|c|}
\hline Statistic results & Equity beta & Asset beta (assume debt beta = 0) \\
\hline MAX & 1,112 & 1,019 \\
\hline MIN & 0,125 & 0,088 \\
\hline MEAN & 0,725 & 0,445 \\
\hline VAR & 0,2148 & 0,1343 \\
\hline \multicolumn{2}{|c|}{ Note: Sample size : 6} \\
\hline
\end{tabular}

\section{C- Hardware listed companies group}

Among 4 groups, this is the group with the biggest number of listed firms and with the highest equity beta value of about 0,75 . However, the asset beta mean of about 0,44 is lower than those of software and comm./telecom industries.

Different from firms in the other industries, 22 listed hardware firms has lower equity and asset beta var values, estimated at 0,108 and 0,089. This presents a more concentrated in level of market risks among firms in this industry. The equity and asset beta mean values are 0,748 and 0,441 are higher than those of 2 previous groups, but they are still good numbers within the estimated max-min range.

Please refer to Exhibit 3 for more information.

Table 6. Statistical results for Vietnam listed Hardware companies

\begin{tabular}{|l|c|c|}
\hline Statistic results & Equity beta & Asset beta (assume debt beta = 0) \\
\hline MAX & 1,234 & 1,069 \\
\hline MIN & 0,200 & 0,054 \\
\hline MEAN & 0,748 & 0,441 \\
\hline VAR & 0,1085 & 0,0893 \\
\hline \multicolumn{2}{|c|}{ Note: Sample size : 22 } \\
\hline
\end{tabular}

\section{D- Comm. \& Telecommunication listed companies group}

Many firms in this category diversify their operation in different business areas. Different from firms in the other three (3) industries, 18 listed comm./telecom firms has wider range of equity and asset beta values. Max beta values of 2,056 and 1,941 are the highest and min beta 
values of $-0,52$ and $-0,25$ are the lowest among 4 groups. This indicates a less concentrated in level of market risks among firms in this industry. The asset beta mean value is 0,46 (the highest) and equity beta mean value is 0,67 (the $2^{\text {nd }}$ highest in 4 groups) shows the financial leverage has impacts on market risk exposure during the crisis period.

Please refer to Exhibit 4 for more information.

Table 7. Statistical results for Vietnam listed Comm. and Telecommunication companies

\begin{tabular}{|l|c|c|}
\hline Statistic results & Equity beta & Asset beta (assume debt beta = 0) \\
\hline MAX & 2,056 & 1,941 \\
\hline MIN & $-0,524$ & $-0,251$ \\
\hline MEAN & 0,671 & 0,462 \\
\hline VAR & 0,2872 & 0,2133 \\
\hline \multicolumn{2}{|c|}{ Note: Sample size : 18} \\
\hline
\end{tabular}

\section{Comparison among 4 groups of computer and electrical companies}

In the below chart, we can see the equity and asset beta value mean of listed firms in the electrical and electronic industry is relatively lower than those of listed software, hardware and comm./telecom firms. It rejects our $1^{\text {st }}$ hypothesis or research issue that the beta values in the electrical and electronic industry would be higher than those in the rest three (3) groups. In term of variance difference, the chart shows that the equity beta variance in electrical/electronic and in hardware industries is lower than those in the rest two, which means the bigger gap in market risk exposure in software and comm./telecom industries. But in general, that the range of equity beta var is from 0,11-0,29 and that of asset beta var is from $0,07-0,21$ is not big. This also rejects our $2^{\text {nd }}$ hypothesis. And both equity and asset beta mean in 4 groups are lower than $(<) 1$, which also rejects our $3^{\text {rd }}$ hypothesis.

Last but not least, the max and min equity and asset beta values of three (3) groups: electrical/electronic, software and hardware industries are close numbers, or have small difference whereas those of comm../telecom groups are much higher. This back-end industry is affected more by market risks. 


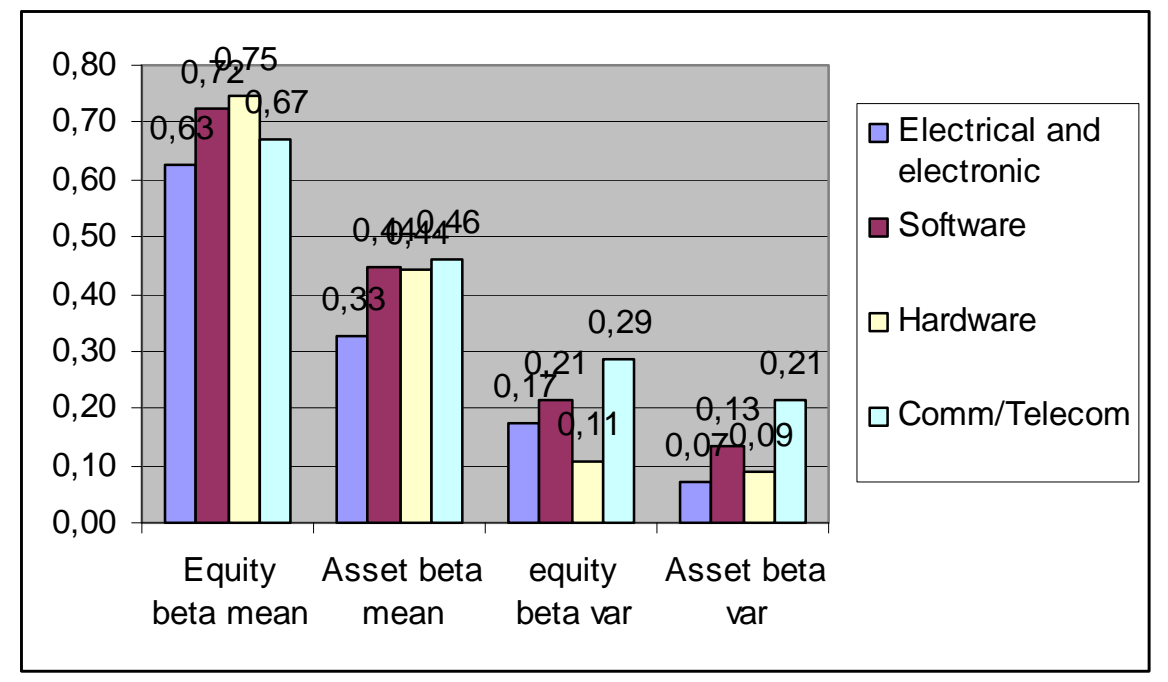

Chart 1. Statistical results of four (4) groups of 64 listed VN computer and electrical firms during/after the crisis period 2007-2011

\section{Risk analysis}

Generally speaking, during the financial crisis 2007-2011, esp. the period 2007-2009, the computer and electrical has certain negative impacts from unexpected increasing price in the materials, and increasing lending interest rates which are affected by the high inflation of $23 \%$ in 2008; so, they could not be decreased in a short time.

Besides, these firms have to face other kinds of risks: technological changing, or an imperfect corporate governance structure, or operational risk. These risks can affect the operating cash flow of these companies.

\section{Conclusion and Policy suggestion}

\section{Electrical and Electronic industry}

This is the industry which has both the lowest equity/asset beta mean values and the lowest asset beta var (0,63 and 0,33, accordingly). During the crisis, this industry has lower market risk and this market is more stable.

After increasing rates period (see exhibit 1), we highly value the efforts of government, central bank and financial institutions having proper policies to support businesses and internal investors, and stabilize inflation.

\section{Software industry}

This is one of industries which can be affected much from the global crisis because of the recession of the whole market. 
However, in a developing market such as Viet Nam, the market is potential and market risks are controllable. The using of DFL or degree of financial leverage can be a vital reason for a decrease in asset beta value of 0,44 from equity beta value of 0,72 .

\section{Hardware industry}

The equity beta variance of this category is the lowest $(0,11)$ among 4 groups although it is the largest group with 22 firms. Its equity beta mean is the highest number $(0,75)$ but under financial leverage condition, its asset beta mean is controllable. It might give a good scenario for the management team of these firms to make a proper evaluation of financial conditions and degree of financial leverage on operating.

\section{Comm./Telecommunication industry}

Through our comparative analysis on asset beta values, this is the industry which has the higher market risk exposure than that of the other three (3) industries when we consider impacts of financial leverage. Also the equity and asset beta variance $(0,29$ and 0,21$)$ show a larger dispersion than, esp., hardware and electrical/electronic firms. The reasons might come from market factors and economic crisis.

In general, our empirical findings state that they are not in favor of our $1^{\text {st }}$ and $2^{\text {nd }}$ and $3^{\text {rd }}$ hypotheses or research issues.

In summary, though Viet Nam is an emerging market with imperfect financial system, the beta values estimated are at acceptable level with $73 \%$ firms in the research sample while just a few companies' beta values are risky (about $27 \%$ firms).

Additionally, it indicates the higher the using of financial leverage, the lower the beta values. In reality, there are $70 \%$ of computer and electrical firms which has $0<$ beta $<1$ in this research sample. The financial crisis might cause troubles for these businesses, but if they can continue to borrow sufficient money from financial markets, it can be good for their risk management.

Furthermore, if we compare these data and values to those of construction and real estate firms in our previous research (see the reference list and exhibit 5), we might see that in here, the beta mean can be a little bit lower. The reason could be the impacts from the crisis on this industrial company groups are less than on the construction and real estate company groups.

Finally, this paper suggests implications for further research and policy suggestion for the Viet Nam government and relevant organizations, economists and investors from current market conditions.

\section{References}

ADB and Viet Nam Fact Sheet. (2010).

Ang, A., \& Chen, J. (2007). CAPM Over the Long Run: 1926-2001. Journal of Empirical Finance. 
Blitz, David., Pang, Juan., \& Vliet, Pim V. (2012). The Volatility Effects on Emerging Markets. SSRN Working paper series.

Cont, R. (2010). Empirical properties of Asset Returns: Stylized facts and Statistical Issues. Quantitative Finance.

Eugene, Fama F., \& French, Kenneth R. (2004). The Capital Asset Pricing Model: Theory and Evidence. Journal of Economic Perspectives.

Eugene, Fama F., \& French, Kenneth R.. (2006). The Value Premium and the CAPM. Journal of Finance.

Fernandez, Pablo. (2008). Levered and Unlevered Beta. SSRN Working paper series.

http://www.hsx.vn/hsx/

http://www.ifc.org/ifcext/mekongpsdf.nsf/Content/PSDP22

http://www.mofa.gov.vn/vi/

Huy, Dinh T.N. (2012). Estimating beta of Viet Nam listed construction companies groups during the crisis. Journal of Integration and Development.

Rogers, Pablo., Securato, and Jose Roberto. (2007). Comparative Study of CAPM, Fama and French Model and Reward Beta Approach in the Brazilian Market. SSRN Working paper series.

\section{Exhibit}

Exhibit 1 - Interest rates, Inflation, GDP growth and macroeconomics factors (source: Viet Nam commercial banks and economic statistical bureau)

\begin{tabular}{|l|l|l|l|l|l|l|}
\hline Year & Basic rates & $\begin{array}{l}\text { Lending } \\
\text { rates }\end{array}$ & $\begin{array}{l}\text { Deposit } \\
\text { rates }\end{array}$ & Inflation & GDP & $\begin{array}{l}\text { USD/VND } \\
\text { rate }\end{array}$ \\
\hline 2011 & $9 \%$ & $18 \%-22 \%$ & $13 \%-14 \%$ & $18 \%$ & $5,89 \%$ & 20.670 \\
\hline 2010 & $8 \%-9 \%$ & $19 \%-20 \%$ & $13 \%-14 \%$ & $\begin{array}{l}11,75 \% \\
\text { Estimated at } \\
\text { Dec 2010) }\end{array}$ & $\begin{array}{l}6,5 \% \\
\text { (expected) }\end{array}$ & 19.495 \\
\hline 2009 & $7 \%$ & $9 \%-12 \%$ & $9 \%-10 \%$ & $6,88 \%$ & $5,2 \%$ & 17.000 \\
\hline 2008 & $8,75 \%-14 \%$ & $19 \%-21 \%$ & $15 \%-16,5 \%$ & $22 \%$ & $6,23 \%$ & 17.700 \\
\hline 2007 & $8,25 \%$ & $12 \%-15 \%$ & $9 \%-11 \%$ & $12,63 \%$ & $8,44 \%$ & 16.132 \\
\hline 2006 & $8,25 \%$ & & & $6,6 \%$ & $8,17 \%$ & \\
\hline 2005 & $7,8 \%$ & \multicolumn{7}{|l|}{$8 \%$} & \\
\hline Note & \multicolumn{7}{|l|}{ Approximately (2007: required reserves ratio at SBV is changed from 5\% to 10\%) } \\
\hline
\end{tabular}


Exhibit 2 - Estimating beta results for Viet Nam Listed Software Companies (as of Dec 2012) (source: Viet Nam stock exchange data)

\begin{tabular}{|c|l|c|c|c|}
\hline $\begin{array}{c}\text { Order } \\
\text { No. }\end{array}$ & Company stock code & Equity beta & $\begin{array}{c}\text { Asset beta (assume } \\
\text { debt beta = 0) }\end{array}$ & Note \\
\hline 1 & $\underline{\text { FPT }}$ & 0,976 & 0,364 & \\
2 & $\underline{\text { CMG }}$ & 0,949 & 0,348 & \multirow{2}{*}{ SRA as comparable } \\
\cline { 2 - 4 } 3 & $\underline{\text { SRB }}$ & 1,051 & 1,019 & \\
4 & $\underline{\text { VLA }}$ & 0,125 & 0,111 & \\
5 & $\underline{\text { HIG }}$ & 1,112 & 0,740 & \\
6 & SRA & 0,137 & 0,088 & \\
\hline
\end{tabular}

Exhibit 3 - Estimating beta results for Viet Nam Listed Hardware Companies (as of Dec 2012) (source: Viet Nam stock exchange data)

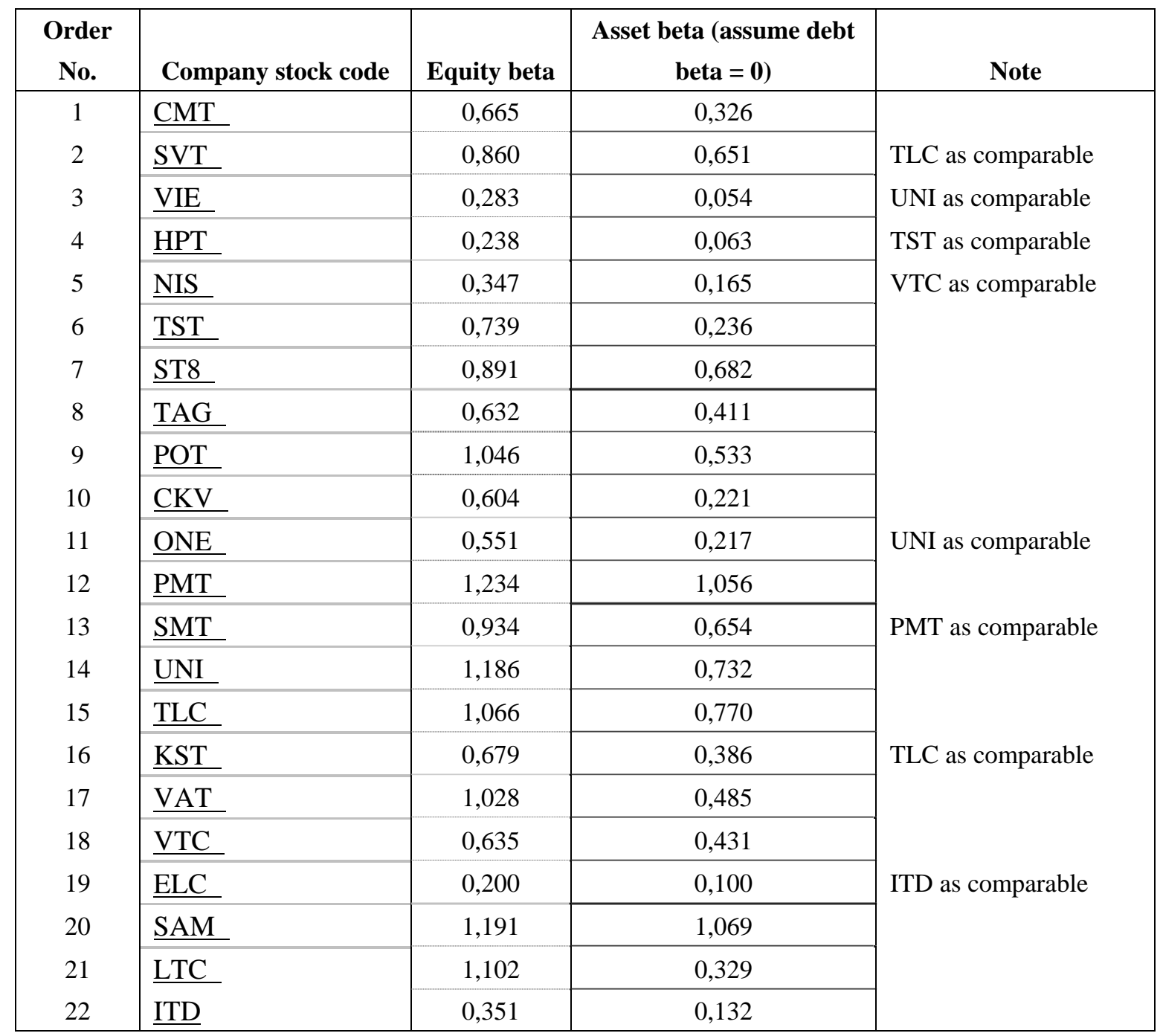


Exhibit 4 - Estimating beta results for Viet Nam Listed Comm. and Telecommunication Companies (as of Dec 2012) (source: Viet Nam stock exchange data)

\begin{tabular}{|c|c|c|c|c|}
\hline $\begin{array}{l}\text { Order } \\
\text { No. }\end{array}$ & Company stock code & Equity beta & $\begin{array}{l}\text { Asset beta (assume } \\
\text { debt beta }=0 \text { ) }\end{array}$ & Note \\
\hline 1 & ECI & 0,708 & 0,527 & \multirow{18}{*}{$\begin{array}{l}\text { ECI as comparable } \\
\text { DHI as comparable }\end{array}$} \\
\hline 2 & INN & 0,195 & 0,104 & \\
\hline 3 & PTP & $-0,524$ & $-0,251$ & \\
\hline 4 & DHI & 0,740 & 0,547 & \\
\hline 5 & $\underline{\mathrm{IHK}}$ & 0,514 & 0,295 & \\
\hline 6 & $\underline{\mathrm{HTP}}$ & 1,091 & 0,846 & \\
\hline 7 & $\underline{\mathrm{TPH}}$ & 0,801 & 0,356 & \\
\hline 8 & IN4 & 0,473 & 0,284 & \\
\hline 9 & $\underline{\mathrm{ADC}}$ & 0,425 & 0,214 & \\
\hline 10 & $\underline{\mathrm{HST}}$ & $-0,042$ & $-0,029$ & \\
\hline 11 & $\underline{\text { SGD }}$ & 1,089 & 0,581 & \\
\hline 12 & DAE & 0,696 & 0,275 & \\
\hline 13 & HEV & 0,633 & 0,434 & \\
\hline 14 & $\underline{\text { ALT }}$ & 0,759 & 0,607 & \\
\hline 15 & $\underline{E F I}$ & 2,056 & 1,941 & \\
\hline 16 & EID & 1,210 & 0,874 & \\
\hline 17 & $\underline{\mathrm{DAD}}$ & 0,625 & 0,423 & \\
\hline 18 & SED & 0,634 & 0,292 & \\
\hline
\end{tabular}

Exhibit 5 - Statistical results of three (3) groups of 103 listed construction firms during crisis period

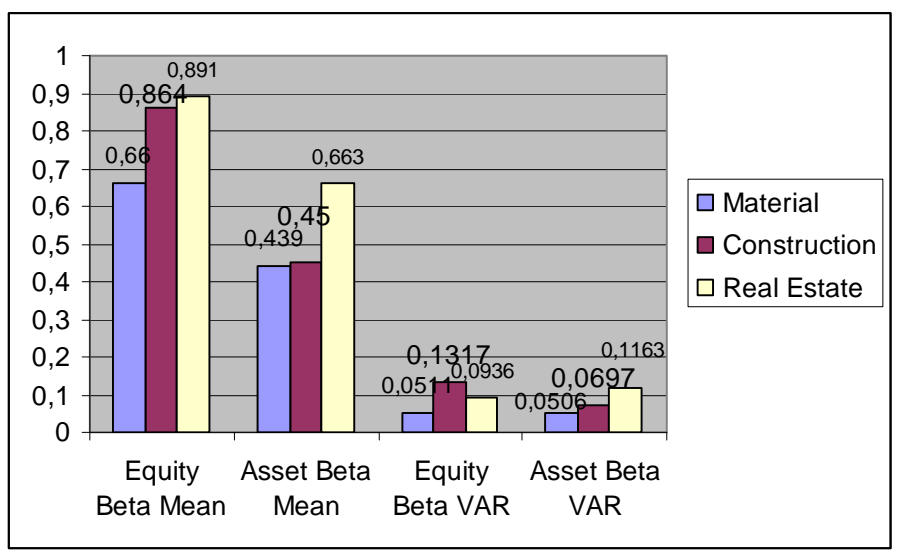

